\title{
An Indefinite Time System of Book Loans in a College Library
}

$M r$. Komidar is reference librarian, Carleton College Library, Northfield, Minn.

$\mathrm{A}^{\mathrm{N}}$ INDEFINITE time loan plan refers to loans of books by a library to its clientele for an extended period. In a college or university library the period of circulation would extend for a semester or for the entire academic year if necessary, unless a book were needed either for reserve or for use by someone else. Such a system of loans is not common in any type of library, high school, public, college, or university. In a public library there is some justification for limiting the loans of books to two weeks, but an indefinite time loan system appears to be a far more satisfactory system for a college or university library. An analysis of student reading reveals little necessity for a college library's requiring a student to return a book within two weeks. Reading is largely curricular and therefore intensive rather than extensive. Books in which class reading assignments are made are generally placed on reserve shelves, depending of course upon the teaching methods of the faculty and the number of copies of books to be read. Books in the general collection, or those not placed on reserve, are used for supplementary reading and source material for term papers. The amount of reading done by students beyond that actually required by an in- structor is relatively limited, and subjects for papers are diversified sufficiently so that the same books will not often be used by more than one or two at a time.

However, before a college or university library can institute an indefinite time loan plan and expect to have it operate successfully, certain conditions must be present. The two most important factors determining the practicability of such a plan are the size and quality of the book collection and the location of the student body. The collection must be a large and comprehensive one which permits a reasonable amount of substitution of titles and provides more than one copy of the titles most in demand. Regardless of the excellence of the book collection, however, the factor which controls the success of the indefinite time loan system is the accessibility of the student body. A system of recalls is essential, and the efficiency with which the recall system operates depends on whether or not the students can be reached easily by telephone or campus mail. Unless it is possible to have a book returned within a day after notification, the plan cannot operate satisfactorily.

It was only after careful consideration of the problems involved that the extended loan plan was adopted by the Carleton College Library in September 1942. To the individual student the extended loan period had obvious advantages, but to the 
student body and the college community as a whole it appeared to have one possible disadvantage. Too many books might become "cold storage" in the students' rooms. Such a situation would handicap those students and faculty who prefer to browse in the stacks before selecting the material that they wish to read at home. To prevent books from becoming "cold storage" for the entire year, it was decided to limit the loan period to a semester. Then at a determined date at the end of each semester all books charged to students were to be returned. Such a system would assure a semiannual replacement of all books on the shelves where they would become generally accessible again, as well as a semiannual clearance of the files and a checkup on books lost, strayed, or stolen.

\section{Routines}

Routines established under the indefinite time loan plan are simple. If the student himself gets the books he wishes to take out, he signs only the book card. The desk attendant stamps the date due slip in the book with the date set at the end of the semester for the return of all books and the book card with the date of the charge. The procedures involved in the recall system are also very simple. All books are subject to recall-immediately if needed for reserve, or after a week if needed by another student, with a full day allowed for the return of the book after the notice has been sent. When someone wishes a book recalled, the desk attendant withdraws the proper card from the files, marks it with the name of the reserve (or the person for whom the book is being recalled), and places it in the "recall" box on the loan librarian's desk. Notices are made out from the cards in the box at intervals during the day and promptly mailed, and the book cards are refiled. Recall cards give the author, title, and call number of the book and indicate the date due. To facilitate checking of returns, a black metal tab is fastened to the top of the card of the volume being recalled. Tabbed cards are checked at eight o'clock each morning and notices sent for overdue books. Black tabs are exchanged for orange ones to indicate overdues. Fines for overdue books are the same as those for reserve books, twentyfive cents per hour per title, beginning at 8:I 5 A.M. the day following the date due.

\section{Recalling Books}

During the entire first semester only three or four recalled books failed to be returned on time, but there was some difficulty experienced with returned books at the end of the first semester. Although students had frequent reminders that books were due on a certain date, there were many who did not return books on time. Not only were all books stamped with the date due, but two weeks before the end of the semester return notices were posted on the main college bulletin board as well as in the library. Of course, this problem existed even when the two-week time limit had been used. Students had been required to return all books at the end of each semester, and there were equally as many books overdue.

Some difficulty had been anticipated with books on the freshman reading lists, since in this case the demands for a comparatively few titles are always heavy. It was suggested that books on these lists should be limited in their circulation as previously. But even under the two-week plan the titles on those lists were always in demand and always out, and unless the student reserved a title, there was very 
little assurance that that title would be available to him on the day it was due. Students were for the most part reluctant to reserve a title. When they wanted a book, they wanted it immediately and would therefore exhaust all possibilities on their lists before asking for a reserve. The situation could not be more unsatisfactory under the extended loan system. In fact, under the recall system established, there were definite possibilities for its improvement. Although there are no statistics, we believe that the students have had a much easier time getting the books they want. The students realize that a book can be recalled immediately if necessary and feel some pressure to complete their use of it as quickly as possible. Recalls have been encouraged. Students were at first slow to take advantage of the recall system, but now they are continually using it. Almost no difficulty has been experienced in getting books returned to the library, and in the six months that the new plan has been in operation there has been only one objection to a recall notice. Students have cooperated well not only in responding to recall notices but in returning books when they are through using them, and books are apparently as readily available as they were under the two-week system.

A check on circulation statistics showed a decrease in the figures for the same period last year, but this drop could be attributed to the current emphasis on the sciences and resultant smaller enrolment in courses requiring extended reading rather than to the indefinite time loan plan. For the sake of comparison, a check was also made on the use of periodicals, which circulate under the same rules as before. The figures showed a corresponding decrease.

Greatly simplified circulation routines resulted from the use of the indefinite time loan system. The revolving date due file was eliminated, and the number of steps necessary for charging or discharging books was reduced. Moreover, under the two-week system the number of overdue books had been large, and the amount of daily time consumed in checking call slips with the card files and stacks and in sending out overdue and fine notices was frequently two hours. Under the new system the checking has been eliminated and the time spent in sending out notices has been reduced about seventy-five per cent.

Finally, the situation in regard to fines has improved. No matter how small the fine was, the collection of fines had always been a source of friction between staff and students. Relationships between staff and students have been friendlier under the new system not only because of the fewer fines that have had to be paid but also because a student who does return a book late can better understand the reason for a penalty if he knows that the book is being recalled because someone else needs it and not just because the library wants it back on the shelves. 